\title{
Adherence to Uroepithelial Cells of Providencia stuartii Isolated from the Catheterized Urinary Tract
}

\author{
By HARRY L. T. MOBLEY, * GWYNN R. CHIPPENDALE, \\ JAMES H. TENNEY AND JOHN W. WARREN \\ Division of Infectious Diseases, University of Maryland School of Medicine, $10 \mathrm{~S}$. Pine Street, \\ Baltimore, Maryland 21201, USA
}

(Received 27 January 1986; revised 27 June 1986)

\begin{abstract}
The long-term catheterized urinary tract appears to offer a niche for Providencia stuartii, otherwise an unusual clinical isolate. $P$. stuartii, the most frequent and persistent isolate from the urine of 51 long-term catheterized patients, was recovered from 761 of $1230(62 \%)$ weekly urine specimens. To test the hypothesis that prevalence of this species may be due to adherence properties of the organism, 20 selected strains from 14 patients at two nursing homes, representing six distinct serotypes and harbouring combinations of nine different plasmid species, were tested for adherence to uroepithelial cells (UEC). Optimal conditions were determined for differentiating strains on the basis of in vitro adherence to UEC. These strains, grown in nutrient broth, were incubated with UEC isolated from the urine of a healthy adult female $\left(10^{8}\right.$ bacteria per $10^{5}$ cells). Washed UEC, retained on $8 \mu \mathrm{m}$ pore diameter filters, were transferred to slides, fixed and stained; bacteria were counted on each of 40 cells. Fourteen of the 20 strains were defined as adherent to UEC by comparison of mean adherent bacteria and percentage of uroepithelial cells with more than 10 bacteria. Adherence was compared to that of a P-fimbriated strain of Escherichia coli. It was not inhibited by $50 \mathrm{~mm}$-mannose. We conclude that the majority of $P$. stuartii isolates are adherent to UEC in vitro and suggest that this may play a role in the persistence of this organism in the catheterized urinary tract.
\end{abstract}

\section{INTRODUCTION}

There are currently many more nursing home beds than acute care hospital beds in the USA (Hing, 1977). Within these nursing homes, urinary incontinence may be a problem for up to $35 \%$ of the patients (Hing, 1977). If other methods are unsuccessful, an indwelling urinary catheter is used to manage incontinence. Bacteriuria, usually polymicrobial, is a universal complication of long-term indwelling catheters. Providencia stuartii is increasingly recognized as a frequent isolate from the urinary tract of chronically catheterized patients, whereas this species is rarely recovered in the acute care setting (Garibaldi et al., 1981; Mobley et al., 1985a; Nyren et al., 1981; Warren et al., 1982; Warren, 1986; Wibell et al., 1980). P. stuartii is prevalent not because of more frequent entry into the catheterized urinary tract but because it is a very persistent inhabitant. Once in the urinary tract, it persists significantly longer than all other bacterial species with the single exception of Escherichia coli and may be isolated for weeks and months after the initial identification (Warren et al., 1982). We can hypothesize that the persistence of $P$. stuartii may be related to adherence properties of the organism. To test this hypothesis it is necessary to be able to differentiate adherent from non-adherent $P$. stuartii strains.

Tissue tropism is often defined by a lectin-like interaction between bacterium and mammalian cell. In vitro assays have, in many instances, been found to correlate with in vivo tissue specificity. Shigella flexneri binds to cells of the descending colon in guinea pigs (Izhar $e t$

Abbreviation: UEC, uroepithelial cell(s). 
al., 1982), Bordetella pertussis to hamster ciliated epithelium (Muse et al., 1977), Pasteurella multocida to rabbit squamous nasopharyngeal cells (Glorioso et al., 1982), Moraxella bovis to corneal epithelial cells (Jackman \& Rosenbusch, 1984), Neisseria meningitidis to human nasopharyngeal cells (Salit \& Morton, 1981), Pseudomonas aeruginosa to human nasal and tracheal cells (Neiderman et al., 1983), and enterotoxigenic $E$. coli to human duodenal enterocytes (Deneke et al., 1983; Knutton et al., 1985). Specificity for the urinary tract has been elegantly documented for some $E$. coli which bind specifically to a digalactoside moiety on the surface of uroepithelial cells via an adhesin encoded by the pap (pyelonephritis-associated pili) operon (Uhlin et al., 1985). The expression of the 'Gal-Gal' binding (mannose-resistant) adhesin is strongly correlated with in vitro uroepithelial adherence and with potential to establish infection of the kidney (Svanborg-Eden et al., 1976; Lomberg et al., 1983; Tullus et al., 1984; O'Hanley et al., 1985). Proteus mirabilis, commonly isolated from the urinary tract, has also been found to adhere to uroepithelial cells in vitro (Svanborg-Eden et al., 1980).

In this report we describe experimental conditions under which strains of Providencia stuartii isolated from the urine of chronically catheterized patients can be differentiated in an in vitro uroepithelial cell adherence assay. Definitions of 'adherent' and 'non-adherent' are proposed and comparisons of the adherence of these $P$. stuartii isolates with that of a uropathogenic strain of $E$. coli are made. A preliminary report of this work has appeared (Mobley et al., 1985b).

\section{METHODS}

Bacterial strains and growth conditions. Strains of $P$. stuartii were isolated from weekly urine specimens obtained over a one-year period from 51 nursing home patients with urinary catheters in place. The patients resided at two geographically separate Baltimore chronic care facilities. Isolates were identified by the Minitek numerical taxonomy system (BBL), and differentiated from other Providencia species by fermentation of adonitol, trehalose and erythritol (Hickman-Brenner et al., 1983). Strains were stored at $-70^{\circ} \mathrm{C}$ in trypticase soy broth (BBL) supplemented with $15 \%(\mathrm{v} / \mathrm{v})$ glycerol.

E. coli SH1 (a Lac ${ }^{-}$derivative of the P and type 1 fimbriated strain J96) was kindly provided by Drs S. and R. Hull, Baylor College of Medicine, Houston, Texas, and was used as a positive control in adherence assays (Hull et al., 1981). E. coli HB101 (pro leu rpsL recA lacYl) was used as a non-adherent control.

Bacteria were recovered from storage by growth on trypticase soy agar (BBL), and subcultured in a variety of media. Liquid cultures were grown with aeration ( 200 r.p.m.) for $18 \mathrm{~h}$ and statically for 24 or $48 \mathrm{~h}$; agar (1.5\%,w/v) plates were incubated for $18 \mathrm{~h}$. All cultures were incubated at $37^{\circ} \mathrm{C}$. Urine agar was prepared by mixing three parts filter-sterilized human urine with one part $6 \%(\mathrm{w} / \mathrm{v})$ agar (Difco). These plates were sealed before incubation. Nutrient Broth, Brain Heart Infusion Broth and Heart Infusion Broth were purchased from Difco. Luria broth and minimal salts medium were prepared according to Miller (1972).

Bacteria grown in liquid media were harvested by centrifugation at $6000 \mathrm{~g}$ for $10 \mathrm{~min}$ at $4{ }^{\circ} \mathrm{C}$. Supernatants were aspirated, cell pellets were well drained, and bacteria were gently suspended in PBS $(0 \cdot 145 \mathrm{M}$-sodium chloride, 0.05 M-sodium phosphate, $\mathrm{pH} 7 \cdot 2)$ with a Pasteur pipette to $\mathrm{OD}_{550} 0.1\left(1 \mathrm{~cm}\right.$ light path) (approximately $2 \times 10^{8}$ bacteria $\mathrm{ml}^{-1}$ as determined by colony counts) unless otherwise indicated. Bacteria from agar plates were gently scraped from the surface with a sterile swab and suspended in a similar fashion.

Haemagglutination assays. Haemagglutination and tannic acid treatment of erythrocytes were done by the method of Old \& Adegbola (1982). Guinea-pig erythrocytes were obtained from Pel-Freez Biologicals (Rogers, Arkansas), ox erythrocytes from Cleveland Scientific (Cleveland, Ohio) and human erythrocytes from the first author.

Uroepithelial cells $(U E C)$. First morning urine of healthy adult females (ages 22-36 years) was transported on ice within $2 \mathrm{~h}$ of collection and UEC were isolated by centrifugation $\left(4000 \mathrm{~g}, 10 \mathrm{~min}, 4^{\circ} \mathrm{C}\right)$, washed three times with cold PBS, pH 7.2, resuspended in $1 \mathrm{ml} \mathrm{PBS}$, quantified in a haemocytometer, and adjusted to a concentration of 2 $\times 10^{5}$ cells ml-1 unless otherwise indicated. The mean number of UEC collected from $100 \mathrm{ml}$ urine was $4.7 \times 10^{5}$ $\pm 3.3 \times 10^{5}(\mathrm{SD}, n=24)$. The mean area that UEC occupied on the microscope slide was determined by calibrating an ocular grid with a stage micrometer; the areas of 40 UEC were measured (see legend to Fig. 1).

Quantification of adherence. Assays were done according to the optimal assay conditions described in Results. Slides were observed under oil immersion $(1000 \times$, total magnification). Single rod-shaped bacteria that touched the border of or rested within the boundary of the UEC were counted on each of the first 40 epithelial cells observed, starting at the top left of the cell imprint. An epithelial cell was counted if it: (1) excluded viability stain completely; (2) had a well-defined border (no overlapping cells); (3) was not folded back onto itself; (4) was in a field free of background bacteria; and (5) was not visibly fragmented. Assays were done in triplicate. Background bacteria are defined as patches of organisms not associated with UEC. Endogenous bacteria are defined as those organisms associated with UEC that were derived from the urinary tract of the UEC donor. 
Plasmid isolation. Plasmid DNA was isolated from $0.5 \mathrm{ml}$ of overnight aerated Luria-broth-grown cultures by extraction with alkaline sodium dodecyl sulphate as described by Birnboim \& Doly (1979). The DNA was electrophoresed on $0.7 \%$ agarose (BRL) gels, stained with ethidium bromide (Sigma) and visualized on a UV transilluminator. Patterns were recorded on Polaroid type 47 film through an orange filter (Wratten filter no. 22A, Kodak), Plasmid sizes were estimated by comparing electrophoretic mobilities to plasmids of known molecular mass.

Electron microscopy. A drop of bacterial cell suspension was placed on a carbon-coated Formvar film on a 200mesh copper grid and negatively stained with $1 \%(\mathrm{w} / \mathrm{v})$ sodium phosphotungstate $(\mathrm{pH} 6.8)$. Specimens were examined in a Siemens IA electron microscope at an accelerating voltage of $80 \mathrm{kV}$.

Serotyping. $P$. stuartii isolates were serotyped by Dr John Penner (University of Toronto, Canada) according to his O-serotyping scheme (Penner et al., 1976).

RESULTS

Optimization of adherence assay

$P$. stuartii was recovered from 761 of $1230(62 \%)$ weekly urine specimens. Adherence assays were done with 20 isolates of $P$. stuartii (Table 1) according to conditions established for $E$. coli by Svanborg-Eden et al. (1977). To provide a basis for differentiating adherent from nonadherent isolates, these data (not shown) were used to select one isolate, AB189, as a strongly adherent strain and one isolate, RO7305, as a poorly adherent strain. These isolates were selected as representatives of adherent and non-adherent, respectively. Strain AB189 agglutinated tannic-acid-treated (but not untanned) ox erythrocytes, was heavily fimbriated as revealed by transmission electron microscopy of negatively-stained specimens, and was not flagellate. Strain RO7305 did not agglutinate tanned or untanned ox erythrocytes, did not express fimbriae, but was flagellate.

To select a single donor of UEC for the assay, adherence assays were done using UEC obtained from first morning urine from six healthy adult females (ages 22-36). Day-to-day reproducibility of mean number of adherent bacteria per UEC for $P$. stuartii strains AB189 and RO7305 and E. coli SH1 was determined, and numbers of endogenous bacteria were measured. One donor was selected whose cells provided consistent adherence values and had acceptable levels of endogenous bacteria ( $<10$ bacteria per UEC). UEC collected from first morning urine of the selected donor were harvested by centrifugation, washed, adjusted to $2 \times 10^{5} \mathrm{cells} \mathrm{ml}^{-1}$ in PBS and incubated at $37^{\circ} \mathrm{C}$. Samples were taken over time and tested for exclusion of the viability stain erythrosin B (Sigma). After $30 \mathrm{~min}$ incubation, $50.0 \%(100 / 200)$ of the UEC were viable; after $60 \mathrm{~min}, 20.5 \%(41 / 200)$ excluded stain. Viability remained at that level $(21.0 \%$; $42 / 200$ ) in samples taken at $180 \mathrm{~min}$.

Washed UEC were mixed with 0 , and from $10^{5}$ to $10^{9}$, nutrient-broth-grown bacteria, incubated for $60 \mathrm{~min}$, filtered through $8 \mu \mathrm{m}$ filters, washed, transferred by pressing onto microscope slides, fixed and stained. Bacteria were counted on each of $40 \mathrm{UEC}$; the results of triplicate experiments are shown in Fig. 1. P. stuartii AB189 adhered more avidly at all ratios than strain RO7305. The diamonds represent the filter background (mean number of bacteria per $1820 \mu \mathrm{m}^{2}$, the mean area of UEC from the donor used in this study). Filter background was unacceptably high when $10^{9}$ bacteria $\mathrm{ml}^{-1}$ were added in the assay. At $10^{8}$ bacteria $\mathrm{ml}^{-1}$ adherence values for strains AB189 and R07305 were significantly different $(P<0.025)$. For these reasons, a ratio of $10^{8}$ bacteria per $10^{5}$ UEC was chosen for the assay.

$P$. stuartii AB189 and $E$. coli SH1 showed peak adherence 10-20 min after mixing (Fig. 2). $P$. stuartii RO7305 showed little adherence above the control to which no bacteria were added.

Adherence assays were done in triplicate with bacteria cultured in eight media under conditions of aeration ( $18 \mathrm{~h}$ ) and static growth $(24$ and $48 \mathrm{~h})$, in tubes of broth and on agar plates $(18 \mathrm{~h})$. Aerated nutrient broth and statically grown urine cultures gave the highest mean adherence values, 27.8 and 22.0 bacteria per UEC, respectively. Statically grown Brain Heart Infusion Broth cultures yielded the lowest values, 9.4 bacteria per UEC. An endogenous value of 8.9 bacteria per UEC was determined. Cultures in minimal salts supplemented with glycerol grown statically and on agar yielded high values but organisms derived from these cultures clumped and were difficult to suspend. Nutrient broth, as for E. coli (Svanborg-Eden et al., 1977), yielded optimal adherence for the $P$. stuartii test strain. 
Table 1. Adherence of selected P. stuartii isolates

\begin{tabular}{|c|c|c|c|c|c|c|}
\hline $\begin{array}{l}P . \text { stuartii } \\
\text { isolate }\end{array}$ & Serotype* & $\begin{array}{c}\text { Estimated } \\
\text { plasmid } \\
\text { size } \\
(\mathbf{k b}) \dagger\end{array}$ & $\begin{array}{c}\text { MR/K } \\
\text { haemag- } \\
\text { gluti- } \\
\text { nation }\end{array}$ & $\begin{array}{l}\text { Adherence } \\
\text { to UEC } \\
\text { (bacteria } \\
\text { per cell)§ }\end{array}$ & $\begin{array}{l}\text { Percentage } \\
\text { of UEC with } \\
>10 \text { bacteria }\end{array}$ & $P \|$ \\
\hline \multicolumn{7}{|c|}{ Nursing home A } \\
\hline D14761 & $O: 24$ & 110 & - & $15 \cdot 9$ & $48 \cdot 3$ & $<0.001$ \\
\hline BA418 & $\mathrm{O}: 24$ & $180,130,92,60$ & + & $11 \cdot 0$ & $31 \cdot 7$ & NS \\
\hline BE 1814 & $0: 25$ & $150,96,79$ & + & $13 \cdot 4$ & $45 \cdot 0$ & $<0.005$ \\
\hline BE 5653 & $\mathrm{O}: 25(\mathrm{O}: 43)$ & 150 & - & $15 \cdot 0$ & $41 \cdot 7$ & $<0.025$ \\
\hline BE3304 & $O: 43$ & 150 & - & $19 \cdot 3$ & $41 \cdot 7$ & $<0.025$ \\
\hline PE4390 & $O: 43$ & - & - & $17 \cdot 4$ & $52 \cdot 7$ & $<0.001$ \\
\hline HA4l & $O: 43$ & - & - & $13 \cdot 2$ & $36 \cdot 7$ & NS \\
\hline TA 1144 & $0: 43$ & 110 & - & $16 \cdot 0$ & $37 \cdot 5$ & NS \\
\hline PL22 & $0: 43$ & 92 & - & 19.7 & $39 \cdot 2$ & NS \\
\hline PL4954 & $0: 52$ & - & - & 9.8 & $25 \cdot 0$ & NS \\
\hline BA 3512 & $\mathrm{NT}^{\mathrm{R}}$ & 110 & - & $21 \cdot 4$ & $61 \cdot 7$ & $<0.001$ \\
\hline RO7305 & $\mathrm{NT}^{\mathrm{S}}$ & - & - & $9 \cdot 2$ & $27 \cdot 5$ & NS \\
\hline \multicolumn{7}{|c|}{ Nursing home B } \\
\hline WE 2020 & $O: 4$ & - & - & $17 \cdot 3$ & $50 \cdot 8$ & $<0.001$ \\
\hline AB 189 & $0: 25$ & -- & + & $23 \cdot 2$ & $60 \cdot 8$ & $<0.001$ \\
\hline AB454 & $\mathrm{O}: 25$ & - & + & $17 \cdot 2$ & $49 \cdot 2$ & $<0.001$ \\
\hline EI1130 & $O: 25$ & 92 & + & 30.9 & $67 \cdot 5$ & $<0.001$ \\
\hline FE4361 & $0: 25$ & - & + & $15 \cdot 2$ & $45 \cdot 8$ & $<0.005$ \\
\hline KE2974 & $0: 25$ & - & + & 29.5 & $64 \cdot 2$ & $<0.001$ \\
\hline EI219 & $\mathrm{NT}^{\mathrm{R}}$ & - & + & 20.9 & $54 \cdot 2$ & $<0.001$ \\
\hline SI3211 & $\mathrm{NT}^{\mathrm{R}}$ & 92,58 & - & $24 \cdot 7$ & $54 \cdot 2$ & $<0.001$ \\
\hline \multicolumn{7}{|c|}{$\begin{array}{l}\text { * } \mathrm{NT}^{\mathrm{R}} \text {, rough, non-typable; } \mathrm{NT}^{\mathrm{S}} \text {, smooth, non-typable. } \\
\dagger-\text {, No detectable plasmids. } \\
\ddagger \text { Haemagglutination of tannic-acid-treated ox erythrocytes. } \\
\S \text { Values are means of three experiments; mean number of endogenous bacteria }=9 \cdot 6 \text {; percentage of } \\
\text { EC with }>10 \text { endogenous bacteria }=26 \cdot 7 \text {. } \\
\| \text { By comparison to the percentage of UEC with }>10 \text { bacteria for endogenous bacteria by chi-squared } \\
\text { st; NS, not significantly higher than endogenous levels or that of strain } \mathrm{RO} 7305 \text {. }\end{array}$} \\
\hline
\end{tabular}

The effect of washes and centrifugations on adherence of $P$. stuartii AB189 was measured (Fig. 3). One wash reduced adherence by $10 \%$ and two washes diminished it by $50 \%$. E. coli $\mathrm{SH} 1$ was similarly affected by the washing procedure. Therefore, for the adherence assay, bacteria were centrifuged, the pellets well drained, and the bacteria suspended to the desired concentration and assayed with no additional centrifugations.

Adherence assays were done using either PBS, $\mathrm{pH} 7 \cdot 2$, or filter-sterilized urine. In triplicate assays, the mean value of adherence for $P$. stuartii AB1 89 in PBS was 20.9 per UEC in both PBS and filter-sterilized urine. Because there was no difference in adherence values, the less offensive PBS was used as the incubation buffer of choice from this point on.

The final assay conditions, optimized by varying a number of factors as described above, were as follows. Equal volumes $(0 \cdot 2-0.5 \mathrm{ml})$ of bacterial suspension $\left(2 \times 10^{8}\right.$ cells $\left.\mathrm{ml}^{-1}\right)$ and UEC suspension $\left(2 \times 10^{5}\right.$ cells $\left.\mathrm{ml}^{-1}\right)$ were mixed in glass tubes $(10 \times 75 \mathrm{~mm})$ in the presence of 50 mm-mannose (Sigma) to prevent mannose-sensitive adherence (Old \& Scott, 1981) to uromucoid (Chick et al., 1981), sealed with silicone rubber stoppers and incubated at $37^{\circ} \mathrm{C}$ on a test-tube rotator at 8.5 r.p.m. (Roto-Mix, Fisher Scientific). After $20 \mathrm{~min}, 0.1 \mathrm{ml}$ erythrosin B $(0.8 \%, \mathrm{w} / \mathrm{v}$, in PBS) was added and incubation was continued for $10 \mathrm{~min}$. The suspension was then filtered through nitrocellulose filters $(8 \mu \mathrm{m}$ pore diameter; Millipore) under $103.5 \mathrm{kPa}$ vacuum and washed three times with $5 \mathrm{ml}$ ice-cold PBS. The filters were removed and UEC were transferred to carefully cleaned glass microscope slides by gentle rolling finger pressure; the filters were peeled from the slide and discarded. The slides were air dried, fixed for $5 \mathrm{~min}$ in $70 \%(\mathrm{v} / \mathrm{v})$ ethanol, stained with freshly diluted Giemsa stain $(1: 50, \mathrm{v} / \mathrm{v})$ for $10 \mathrm{~min}$, rinsed with 


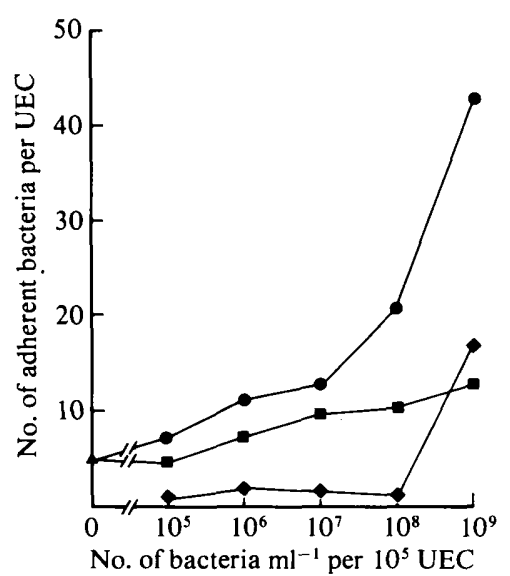

Fig. 1

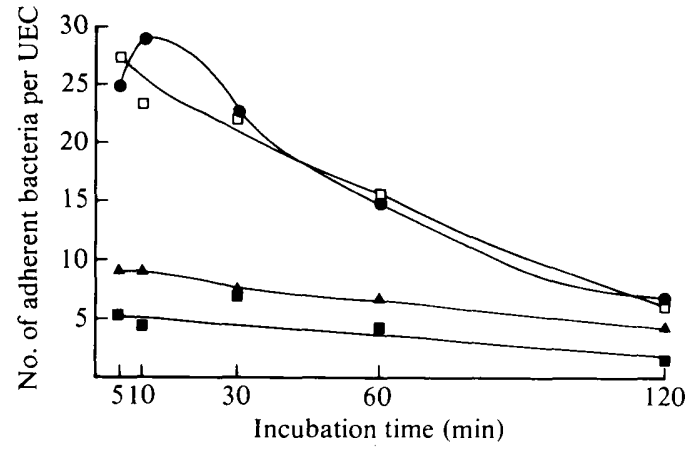

Fig. 2

Fig. 1. Effect of ratio of bacteria to UEC on adherence. UEC $\left(0.5 \mathrm{ml}, 10^{5}\right.$ cells $)$ were incubated with various concentrations of bacteria in $0.5 \mathrm{ml}$ for $60 \mathrm{~min}$ at $37^{\circ} \mathrm{C}$. Suspensions were filtered through $8 \mu \mathrm{m}$ pore diameter nitrocellulose filters and washed three times with $5 \mathrm{ml}$ PBS, pH 7.2. Cells were transferred to slides, dried, fixed, and adherent bacteria on each of 40 UEC were counted. Filter background was estimated by counting bacteria within 40 random fields of $1820 \mu \mathrm{m}^{2}$ (mean area of a uroepithelial cell) that contained no epithelial cells. Results are the mean of three experiments. $P$, $P$. stuartii AB189;, , P. stuartii RO7305; , filter background.

Fig. 2. Effect of incubation time on bacterial adherence to UEC. Bacteria $\left(10^{8}\right.$ per $\left.0.5 \mathrm{ml}\right)$ were mixed with UEC $\left(10^{5}\right.$ per $\left.0.5 \mathrm{ml}\right)$ and incubated for various times at $37^{\circ} \mathrm{C}$. Cells were filtered, washed and prepared for microscopy as described in Methods, and bacteria were counted on each of 40 UEC. Results are the mean of three experiments. O, P. stuartii $\mathrm{AB} 189 ; \square$, E. coli $\mathrm{SH} 1, \mathbf{\Delta}, P$. stuartii $\mathrm{RO} 7305$; $\square$, no added bacteria.

distilled water, and air dried. Control slides of (1) no added bacteria (endogenous), (2) adherent $E$. coli $\mathrm{SH} 1$ and (3) non-adherent $E$. coli $\mathrm{HB} 101$ were included with each run.

\section{Distribution of adherent bacteria}

To determine the distribution patterns of adherent bacteria to UEC, the results from all assays done under what were determined to be the optimal conditions were pooled. The percentage of total UEC bearing a given range of bacteria is shown in Fig. 4 for the adherent strain AB189, the non-adherent strain RO7305, the UEC control, and P-fimbriated E. coli SH1. Strain RO7305 and the control showed similar distributions of adherent bacteria and yielded means (arrows) that were not significantly different $(P>0 \cdot 1)$. Strain AB189 showed a broad distribution of number of bacteria per UEC, quite distinct from RO7305, the control, and E. coli SH1. Despite the large standard deviation (represented by the bar extending to the right of the arrow) the mean of 27.3 bacteria per UEC was significantly different from that of RO7305, the control and $E$. coli $\mathrm{SH} 1$ (Table 2). The distribution pattern of AB189 was also found to be significantly different $(P<0.001)$ from that of RO7305, the epithelial cell control and $E$. coli SHI when the data were analysed by the Kolmogorov-Smirnov Test (Sokal \& Rohlf, 1981). When these data are reported as the percentage of UEC with more than 10 bacteria, the values for $P$. stuartii $\mathrm{AB} 189$ and $E$. coli $\mathrm{SH} 1$ are also significantly greater than those for $P$. stuartii RO7305 and endogenously adhering bacteria (Table 2). Values for $E$. coli were intermediate between those for P. stuartii $\mathrm{AB} 189$ and $\mathrm{RO} 7305$.

\section{Adherence to squamous versus transitional epithelial cells}

To determine whether $P$. stuartii preferentially adheres to squamous epithelium which lines the urethra or to transitional epithelial cells, found predominantly on the bladder wall, adherence values were obtained for both squamous and transitional cells. Cell types were 


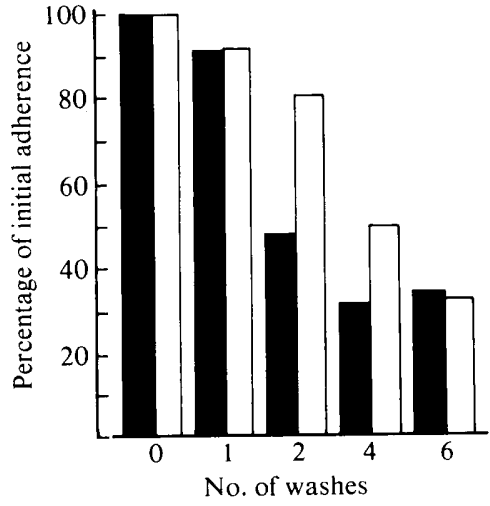

Fig. 3
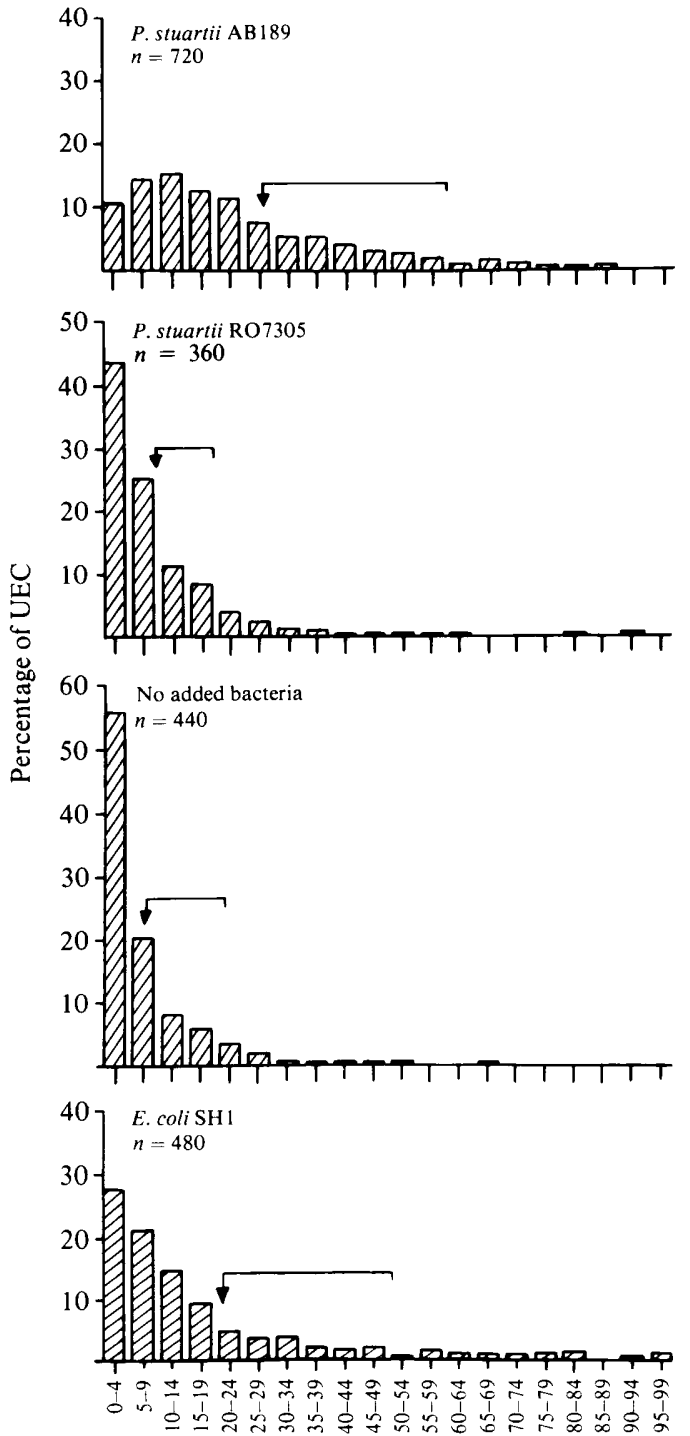

No. of bacteria per UEC

Fig. 4

Fig. 3. Effect of washing of bacteria on adherence. Bacteria grown in nutrient broth with aeration at $37^{\circ} \mathrm{C}$ were harvested by centrifugation at $6000 \mathrm{~g}$ for $10 \mathrm{~min}$ at $4{ }^{\circ} \mathrm{C}$, suspended to a concentration of $10^{8}$ per $0.5 \mathrm{ml}$ and either mixed with UEC $\left(10^{5}\right.$ per $\left.0.5 \mathrm{ml}\right)$ immediately, or subjected to additional washes before mixing. Suspensions were incubated for $30 \mathrm{~min}$ at $37^{\circ} \mathrm{C}$, filtered, transferred to slides, dried, fixed, stained, and bacteria on each of $40 \mathrm{UEC}$ were counted. All experiments were done in triplicate. $\square$, P. stuartii AB189 (100\% equals $23 \cdot 2$ bacteria per UEC): $\square$, E. coli SH1 (100\% equals $19 \cdot 5$ bacteria per UEC).

Fig. 4. Frequency distribution of numbers of bacteria per UEC. Results from all adherence assays done under the optimal conditions determined (see Results) were pooled; the percentage of UEC bearing a given number of bacteria is plotted for $P$. stuartii AB189, $P$. stuartii $\mathrm{RO} 7305$, endogenous bacteria and $E$. coli SH1. $n$ is the number of UEC for which adherent bacteria were quantified. The arrow in each panel indicates the mean; the bar spans one standard deviation (see Table 2). $P$. stuartii strains were grown in nutrient broth; E. coli $\mathrm{SHI}$ was grown on trypticase soy agar. 
Table 2. Adherence values for test strains

\begin{tabular}{|c|c|c|c|c|}
\hline Strain & $\begin{array}{c}\text { Mean no. of } \\
\text { bacteria per UEC } \\
\pm \text { SD }\end{array}$ & $P^{*}$ & $\begin{array}{c}\text { No. of UEC with } \\
>10 \text { bacteria/ } \\
\text { total UEC }\end{array}$ & $P \dagger$ \\
\hline $\begin{array}{l}\text { No added bacteria } \\
\text { (endogenous bacteria) }\end{array}$ & $8 \cdot 2 \pm 14 \cdot 1$ & - & $88 / 440(20.0 \%)$ & - \\
\hline P. stuartii RO7305 & $9 \cdot 2 \pm 11 \cdot 0$ & $>0 \cdot 1$ & $102 / 360(28 \cdot 3 \%)$ & $<0.008$ \\
\hline P. stuartii AB 189 & $27 \cdot 3 \pm 32 \cdot 8$ & $<0.0001$ & $526 / 720(73 \cdot 1 \%)$ & $<0.0001$ \\
\hline E. coli $\mathrm{SHI}$ & $20.9 \pm 29.4$ & $<0.0001$ & $221 / 480(46.0 \%)$ & $<0.0001$ \\
\hline
\end{tabular}

* Mean and standard deviation compared with that for endogenous bacteria by the $t$-test.

$\dagger$ Ratio compared with that for endogenous bacteria by chi-squared test.

distinguished strictly by morphology. Of viable cells obtained from urine of a single donor, $97.9 \%(2463 / 2515)$ were of squamous morphology and $2 \cdot 1 \%(52 / 2515)$ were of transitional morphology. Using strain AB189, the mean adherence value for squamous cells was 26.8 bacteria per UEC (160 UEC, four assays) and that for transitional cells was 27.9 bacteria per UEC (27 UEC, four assays).

\section{Adherence of selected $P$. stuartii isolates}

To determine adherence properties for other isolates of $P$. stuartii, assays were done under optimal conditions for selected isolates. Twenty isolates from 14 patients at two chronic care facilities representing at least six serotypes and harbouring combinations of nine plasmids were assayed. The results (Table 1) show that 17 isolates had 13 or more bacteria per epithelial cell and six strains adhered with a mean of more than 20 bacteria per UEC. Three isolates had fewer than 13 bacteria per UEC. Within this group of strains there were no correlations between serotype and adherence values or plasmid content and adherence values.

\section{DISCUSSION}

We report that strains of $P$. stuartii isolated from the urine of chronically catheterized patients can be differentiated as adherent or non-adherent to UEC on the basis of a standardized in vitro adherence assay. This assay combines features from several previous reports (Chick et al., 1981; Reid et al., 1983; Schaeffer et al., 1979; Svanborg-Eden et al., 1977) and provides ease of sample preparation and accurate evaluation of adherent bacteria.

The decision to quantify adherent bacteria by direct visualization rather than by addition of radiolabelled organisms was based on the types of information that could be obtained. (1) By observing cells directly, viable cells could be singled out for counting and non-viable cells excluded. In addition, the percentage of viable epithelial cells could be assessed at the end of each experiment. (2) Endogenously bound and background bacteria could be accurately assessed. A high endogenous flora has been shown to protect against adherence of exogenously added bacteria (Chan et al., 1984). The possibility of inhibition by endogenous bacteria would not be detected in the routine assay quantifying radiolabelled bacteria. (3) Direct observation also allows the investigator to avoid areas of non-specific background bacteria or adherence of organisms to cellular and non-cellular debris. (4) By direct visualization, we can quantify adherence to both squamous epithelial cells which originate primarily from the lining of the urethra, and transitional epithelial cells that line the bladder wall. In the catheterized urinary tract, we might speculate that adherence to transitional epithelium would establish a more important reservoir than adherence to squamous cells. (5) The distribution of bacteria on epithelial cells can be examined; that is, the number of bacteria on each cell can be quantified, which is not possible when radiolabelled bacteria are used.

During the assay, repeated washing of bacteria before incubation diminished adherence (Fig. 
3). This observation is consistent with disruption of bacterial surface structures (Svanborg-Eden \& Hanson, 1978), suggesting that fimbriae may be involved in $P$. stuartii adherence. Three kinds of haemagglutinins (MS, MR/K and MR/P) have been described for $P$. stuartii (Old \& Scott, 1981 ; Old \& Adegbola, 1982) and have been correlated with morphologically distinct fimbriae. In our assays, the addition of mannose had no effect on adherence values, suggesting that mannose-sensitive haemagglutinins did not play a role in adherence to UEC. Eight of 20 strains expressed the MR/K haemagglutinin (Table 1) and, although the value 'percentage of UEC with $>10$ bacteria' tended to be higher for these strains than for those not expressing the $M R / K$ haemagglutinin ( 52 versus 43 , respectively), there was no significant difference between the groups $(P=0.08)$.

In most reports using in vivo adherence assays, values for adherent bacteria are reported as the mean number of bacteria per UEC. Many reports include adherence values with rather narrow standard deviation ranges about the mean as a result of individual assays (Bruce et al., 1983; Reid et al., 1983, 1984; Svanborg-Eden et al., 1977). We observed a broad distribution pattern (Fig. 4), which was also reported for a limited number of observations by Mardh et al. (1979). This may be due to the large range in size of UEC, the mean area of which was found by us to be $1820 \pm 915 \mu \mathrm{m}^{2}$. Moreover, the distributions of adherent bacteria (Fig. 4) were neither normal nor Poissonian, but were skewed, suggesting that the mean and standard deviation are not the ideal measure of adherence. We suggest that the value 'percentage of UEC with $>10$ adherent bacteria' (Tables 1 and 2) may also prove valuable in assessing adherence. This value does not assume a normal distribution, can be compared with other values by the chi-squared test, and does not give undue weight to a few cells with large numbers of bacteria per UEC.

Although numerous reports present values for mean number of bacteria per UEC \pm standard deviation, what can we consider to be 'adherent'? When we compare such values for $P$. stuartii $\mathrm{AB} 189$ and RO7305 with values obtained when no exogenous bacteria are added, we find that values for AB189 are significantly greater than endogenous values (Table 2), whereas values for RO7305 are not significantly higher than for endogenous organisms. By this definition we can therefore say that strain AB189 is adherent and strain RO7305 is not adherent. By adopting a significance level of $P=0.01$ and using values determined experimentally (Table 2 ) for the nonadherent RO7305 and using mean adherence values \pm standard deviation for triplicate assays $(3 \times 40 \mathrm{UEC})$, a cut-off point for statistically significant adherence can be calculated to be about 13 bacteria per UEC. Using this value, 17 of the strains listed in Table 1 can be called adherent while 3 are not. As a comparison, the P-fimbriated E. coli SHl (derived from the pyelonephritogenic strain J96) adhered with values comparable to (Figs 2 and 3 ) or slightly less than (Fig. 4, Table 2) P. stuartii AB189. The literature cites examples of E. coli (Bruce et al., 1983: Chas: \& Bruce, 1983; Chan et al., 1984; Reid et al., 1983; Svanborg-Eden et al., 1976, 1977), Klebsiella pneumoniae (Bruce et al., 1983) and Pseudomonas aeruginosa (Bruce et al., 1983) strains adhering with values of more than 75 bacteria per UEC, but values of 12 and fewer bacteria per UEC (after subtraction of endogenous bacteria) are also reported (Chick et al., 1981 ) for E. coli displaying mannose-resistant haemagglutination of human erythrocytes. One report of adherence of Proteus mirabilis (Svanborg-Eden et al., 1980), the most closely related of these species to $P$. stuartii, described mean adherence values for groups of strains derived from blood, stool and urine ranging from 21 to 41 bacteria per UEC.

If we compare adherence of the isolates listed in Table 1 by 'percentage of UEC with $>10$ bacteria', 14 of the 20 isolates demonstrated significantly higher values than endogenous levels or that of the non-adherent RO7305. These same isolates showed significant adherence by comparison of means and standard deviations of the numbers of bacteria per UEC.

In our studies we have observed $P$. stuartii to be the most common isolate in chronically catheterized individuals (Mobley et al., 1985a; Warren et al., 1982). Additionally, once the organism gains entrance to the urinary tract, it can be isolated persistently weeks or months after initial isolation (Warren et al., 1982). It is our hypothesis that the persistence of $P$. stuartii is due to adherence to some component of the urinary tract, whether it be UEC as reported here, soluble glycoproteins such as Tamm-Horsfall protein (Ørskov et al., 1980), or a foreign body such as a urinary catheter. We are pursuing this hypothesis. 
We gratefully acknowledge Natalie Mobley for providing countless morning specimens and Linda Horne for expert manuscript preparation.

This work was supported by Public Health Service grant PO1 AG04393-01 Al from the National Institute on Aging of the National Institutes of Health to J.W.W., H. L.T.M. and J.H.T.

\section{REFERENCES}

Alkan, M., Ofek, I. \& Beachey, E. H. (1977). Adherence of pharyngeal and skin strains of group A streptococci to human skin and oral epithelial cells. Infection and Immunity 18, 555-557.

BiRnboim, H. C. \& Doly, J. (1979). A rapid alkaline extraction procedure for screening recombinant plasmid DNA. Nucleic Acids Research 7, 1513-1523.

Bruce, A. W., Chan, R. C. Y., Pinkerton, D., Morales, A. \& Chadwick, P. (1983). Adherence of gram-negative uropathogens to human uroepithelial cells. Journal of Urology 130, 293-298.

ChAN, R. C. Y. \& BRUCE, A. W. (1983). The influence of growth media on the morphology and in vitro adherence characteristics of gram-negative urinary pathogens. Journal of Urology 129, 411-417.

Chan, R. C. Y., Bruce, A. W. \& Reid, G. (1984). Adherence of cervical, vaginal and distal urethral normal microbial flora to human uroepithelial cells and the inhibition of adherence of gram-negative uropathogens by competitive exclusion. Journal of Urology 131, 596-601.

Chick, S., Harber, M. J., Mackenzie, R. \& Asscher, A. W. (1981). Modified method for studying bacterial adhesion to isolated uroepithelial cells and uromucoid. Infection and Immunity 34, 256-261.

Deneke, C. F., MCGowan, K., ThoRne, G. M. \& GoRBACH, S. L. (1983). Attachment of enterotoxigenic Escherichia coli to human intestinal cells. Infection and Immunity 39, 1102-1106.

Garibaldi, R. A., Brodine, S. \& Matsumiya, S. (1981). Infections among patients in nursing homes: policies, prevalence, and problems. New England Journal of Medicine 305, 731-735.

Glorioso, J. C., Jones, G. W., Rush, H. G., Pentler, L. J., DARIF, C. A. \& CoWARD, J. E. (1982). Adhesion of type A Pasteurella multocida to rabbit pharyngeal cells and its possible role in rabbit respiratory tract infections. Infection and Immunity 35, 1103-1109.

Hickman-Brenner, F. W., Farmer, J. J., III, SteIGerwalt, A. G. \& Brenner, D. J. (1983). Providencia rustigianii : a new species in the family Enterobacteriaceae formerly known as Providencia alcalifaciens biogroup 3. Journal of Clinical Microbiology 17, 10571060.

HING, E. (1977). Characteristics of nursing home residents, health status, and care received (Vital and Health Statistics, Series 13. Data from the National Health Survey no. 51). US Department of Health and Human Services Publication no. PHS 81-1712.

Hull, R. A., Gill, R. E., Hsu, P., Minshew, B. H. \& FALKOW, S. (1981). Construction and expression of recombinant plasmids encoding type 1 or D-mannose-resistant pili from a urinary tract infection Escherichi coli isolate. Infection and Immunity 33, 933-938.

Izhar, M., Nuchamowitz, Y. \& Mirelman, D. (1982). Adherence of Shigella flexneri to guinea pig intestinal cells is mediated by a mucosal adhesion. Infection and Immunity 35, 1110-1118.

JACKMAN, S. H. \& RosenbuSCH, R. F. (1984). In vitro adherence of Moraxella bovis to intact corneal epithelium. Current Eye Research 3, 1107-1112.

Knutton, S., Lloyd, D. R., Candy, D. C. A. \& MCNEISH, A. S. (1985). Adhesion of enterotoxigenic Escherichia coli to human small intestinal enterocytes. Infection and Immunity 48, 824-831.

LOMBERG, H., HANSON, L. A., Jacobsson, B., Jodal, U., Leffler, H. \& Svanborg-Eden, C. (1983). Correlation of $\mathrm{P}$ blood group, vesicoureteral reflux, and bacterial attachment in patients with recurrent pyelonephritis. New England Journal of Medicine 308, 1189-1192.

Mardh, P. A., Colleen, S. \& Hovelius, B. (1979). Attachment of bacteria to exfoliated cells from the urogenital tract. Investigative Urology 16, 322-326.

MILlER, J. H. (1972). Experiments in Molecular Genetics. Cold Spring Harbor, NY: Cold Spring Harbor Laboratory.

Mobley, H. L. T., Chippendale, G. R., Fraiman, M. H., Tenney, J. H. \& Warren, J. W. (1985a). Variable phenotypes of Providencia stuartii due to plasmid-encoded traits. Journal of Clinical Microbiology 22, 851-853.

Mobley, H. L. T., Tenney, J. H. \& Warren, J. W. $(1985 b)$. Adherence to uroepithelial cells of Providencia stuartii isolated from catheterized urinary tracts. Abstracts of the Annual Meeting of the American Society for Microbiology 1985, B106, p. 35.

Muse, K. E., Collier, A. M. \& Baseman, J. B. (1977). Scanning electron microscopic study of hamster tracheal organ cultures infected with Bordetella pertussis. Journal of Infectious Diseases 136, 768-777.

NiEderman, M. S., Rafferty, T. D., SaSaki, C. T., Merrill, W. M., Matthay, R. A. \& Reynolds, H. Y. (1983). Comparison of bacterial adherence to ciliated and squamous epithelial cells obtained from the human respiratory tract. American Review of Respiratory Diseases 127, 85-90.

Nyren, P., Runeberg, L., Kostiala, A. I., RenKonen, O.-V. \& RoIne, R. (1981). Prophylactic methenamine hippurate or nitrofurantoin in patients with an indwelling urinary catheter. Annals of Clinical Research 13, 16-21.

O'Hanley, P., Low, D., Romero, I., LARK, D., Vosti, K., Falkow, S. \& Schoolnik, G. (1985). Gal-Gal binding and hemolysin phenotypes and genotypes associated with uropathogenic Escherichia coli. New England Journal of Medicine 313, 414-420.

OLd, D. C. \& AdEgBolA, R. A. (1982). Haemagglutinins and fimbriae of Morganella, Proteus, and Providencia. Journal of Medical Microbiology 16, 427431.

Old, D. C. \& Scotr, S. S. (1981). Hemagglutinins and fimbriae of Providencia spp. Journal of Bacteriology 146, 404-408. 
ØRSKov, I., FERENCZ, A. \& ØRSKov, F. (1980). TammHorsfall protein or uromucoid is the normal urinary slime that traps type 1 fimbriated Escherichia coli. Lancet 2, 887.

Penner, J. L., Hinton, N. A., Hennessy, J. N. \& Whiteley, G. R. (1976). Reconstitution of the somatic (O-) antigenic scheme for Providencia and preparation of O-typing antisera. Journal of Infectious Diseases 133, 283-292.

ReID, G., Brooks, H. J. L. \& BaCoN, D. F. (1983). In vitro attachment of Escherichia coli to human uroepithelium cells: variation in receptivity during the menstrual cycle and pregnancy. Journal of Infectious Diseases 148, 412-421.

ReID, G., Zorzitto, M. L., Bruce, A. W., JeWetT, M. A. S., Chan, R. C. Y. \& Costerton, J. W. (1984). Pathogenesis of urinary tract infection in the elderly: the role of bacterial adherence to uroepithelial cells. Current Microbiology 11, 67-72.

SAlit, I. E. \& Morton, G. (1981). Adherence of Neisseria meningitidis to human epithelial cells. Infection and Immunity 31, 430-435.

SChaeffer, A. J., Amundsen, S. K. \& SChMidt, L. N (1979). Adherence of Escherichia coli to human urinary tract epithelial cells. Infection and Immunity 24, 753-759.

Sobel, J. D. \& Muller, G. (1984). Pathogenesis of bacteriuria in elderly women : the role of Escherichia coli adherence to vaginal epithelial cells. Journal of Gerontology 39, 682-685.

SOKal, R. R. \& Rohlf, F. J. (1981). Biometry, 2nd edn, pp. 440-445. New York: W. H. Freeman.

SVANBorG-EDEN, C. \& HANSON, H. A. (1978). Escherichia coli pili as possible mediators of attachment to human urinary tract epithelial cells. Infection and Immunity 21, 229-237.

Svanborg-Eden, C., Jodal, U., Hanson, L. A., LindBERG, U. \& AKERLUND, A. S. (1976). Variable adherence to normal human urinary-tract epithelial cells of Escherichia coli strains associated with various forms of urinary-tract infection. Lancet 2, 490-492.

Svanborg-Eden, C., Eriksson, B. \& Hanson, L. A. (1977). Adhesion of Escherichia coli to human uroepithelial cells in vitro. Infection and Immunity $\mathbf{1 8}$, 767-774.

SVAnborg-Eden, C., LaRsSon, P. \& Lomberg, H. (1980). Attachment of Proteus mirabilis to human urinary sediment epithelial cells in vitro is different from that of Escherichia coli. Infection and Immunity 27, 804-807.

Tullus, K., Horlin, K., Svenson, S. B. \& Kallenius, G. (1984). Epidemic outbreaks of acute pyelonephritis caused by nosocomial spread of $\mathbf{P}$ fimbriated Escherichia coli in children. Journal of Infectious Diseases 150, 728-736.

Uhlin, B. E., Norgren, M., BaGa, M. \& Normark, S. (1985). Adhesion to human cells by Escherichia coli lacking the major subunit of a digalactoside-specific pilus-adhesin. Proceedings of the National Academy of Sciences of the United States of America 82, 1800 1804.

Warren, J. W. (1986). Providencia stuartii: a common cause of antibiotic-resistant bacteriuria in long-term catheterized patients. Reviews of Infectious Diseases 8, 61-67.

Warren, J. W., Tenney, J. H., Hoopes, J. M., Muncie, H. L. \& ANThony, W. C. (1982). A prospective microbiologic study of bacteriuria in patients with chronic indwelling urethral catheters. Journal of Infectious Diseases 146, 719-723.

Wibell, L., Scheynius, A. \& Norrman, K. (1980). Methenamine-hippurate and bacteriuria in the geriatric patient with a catheter. Acta medica scandinavica 207, 469-473. 